American Journal of Environmental Sciences 7 (3): 224-236, 2011

ISSN 1553-345X

(C) 2011 Science Publications

\title{
Effect of Different Exogeneous Compounds on Biosorption of Endosulfan
}

\author{
${ }^{1}$ Deepika Dave and ${ }^{2}$ A.K. Dikshit \\ ${ }^{1}$ Department of Process Engineering and Applied Science, \\ Dalhousie University, Halifax, NS B3J 2X4, Canada \\ ${ }^{2}$ Centre for Environmental Science and Engineering, \\ Indian Institute of Technology Bombay, Powai, Mumbai 400 076, India
}

\begin{abstract}
Problem statement: Organochlorine pesticide endosulfan is widely used as a replacement for DDT and dieldrin in many parts of the world. Presence of residual pesticides in the water, air and soil environment was confirmed since 1960s. Such Persistent Organic Pollutants (POPs) are of concern because of their long-term subtle effects on hormones, the immune system and reproduction. Therefore, it becomes imperative to develop indigenous technologies for remediation of endosulfan in contaminated water and contaminated sites. Comparison to conventional pesticide removal techniques, biosorption is a kind of promising technique that can accumulate organic and inorganic matter from aqueous solution. The presence of exogenous compounds might shows significant influence on the performance of biosorption/adsorption process and it may become necessary to perform certain pretreatment to diminish their impacts. Approach: The effects of $\mathrm{pH}$, size of biosorbent, ionic strength, presence of inorganic substances such as calcium ion, magnesium ions, chloride ions, fertilizers and presence of organic substances such as dissolved organic matter, surfactant and other pesticides on biosorption of endosulfan onto biosorbent prepared from fungal culture Aspergillus Nidulans (ANS) was investigated in this study. Results: The removal efficiency was more for fine biosorbent particles. Maximum removal of endosulfan was observed at $\mathrm{pH} 6.4$ and no significant effect was found with variation of ionic strength. The presence of chloride, magnesium and calcium ions and surfactant did not affect the removal significantly. The presence of fertilizers such as Urea and Single Super Phosphate did not affect the removal efficiency significantly. Background dissolved organic matter (as humic and polyacrylic acids) was found affecting the removal efficiency of endosulfan significantly. Both the co-sorbents viz. atrazine and monocrotophos almost equally hindered the sorption capacity of ANS biosorbent for the biosorption of endosulfan. Conclusion: Exogenous parameters played an important role in removal efficiency of endosulfan during the biosorption process by ANS biosorbent. There is a need for pretreatment in order to design integrated endosulfan biosorption treatment with concern of the substances present along with endosulfan in water environment.
\end{abstract}

Key words: Endosulfan, atrazine, monocrotophos, pesticides, Aspergillus Nidulans (ANS), surfactant, fertilizers, humic acids, polyacrylic acid

\section{INTRODUCTION}

A highly controversial agrichemical colorless solid endosulfan is an organochlorine compound used as an insecticide and acaricide on cotton crops, field crops such as paddy, sorghum, oil seeds and pulses, as well as vegetables and fruit crops (Goswami et al., 2009). It has been banned in more than 50 countries, including the European Union and several Asian and West African nations, due to its acute toxicity, potential for bioaccumulation and role as an endocrine disruptor. It is still extensively used in many other countries including India, Brazil, USA and Australia. Endosulfan abundant usage and potential for environmental transport has perceived its contamination in soil, water, air and food products. Endosulfan is a priority pollutant for international environmental agencies (Sudhakar and Dikshit, 1999). These health and environmental concerns have lead to an interest in detoxification of endosulfan in the environment. The guideline value for endosulfan and metabolites in drinking water is set 0.22 $\mu \mathrm{g} / \mathrm{l}-0.1-0.2 \mathrm{mg} \mathrm{L}^{-1}$ in agricultural products by USEPA (1999). As per BIS (Bureau of Indian Standards), the pesticide residue should be absent in drinking water and

Corresponding Author: Deepika Dave, Department of Process Engineering and Applied Science, Dalhousie University, Halifax, Nova Scotia, Canada Tel: (902) 494-6580 
should not exceed $0.005 \mathrm{mg} \mathrm{L}^{-1}$ in surface waters (Sudhakar and Dikshit, 2001; Gora et al., 2006). It is exceptionally difficult in research to produce a single method removal treatment for the wide range of pesticides or herbicides in use, which applies unanimously. Several methods either independent or in conjunction are available for the removal of pesticides such as photocytalysis (Farre et al., 2006), chemical oxidation and biological oxidation, nanofiltration membranes (Shaalan et al., 2007) ozonation (Maldonado et al., 2006), biological degradation (Katsoyiannis and Samara, 2005), fenton degradation (Oller et al., 2006) and adsorption (Kouras et al., 1998; Thacker et al., 1997; Gonzalez-Pradas et al., 1997; Francis and Lee, 1972). All conventional methods for the removal of pesticides are found to be either uneconomical or insufficient (Gupta et al., 2002; Kiso et al., 2001; Jury et al., 1984). Therefore, it becomes essential to search for effective and economical alternative method to overcome the constraints of convention methods. Biological method such as biosorption is an attractive and promising alternative which accumulate organic and inorganic matter including metal, dyes, phenols and pesticides and offers potential advantages such as low operating cost, minimization of chemical or biological sludge (Ahluwalia and Goyal, 2007; Maurya et al., 2006). For several decades, biosorption technique has proved its effectiveness for the bioaccumulation of heavy metal rich wastewaters (Rana et al., 2009; Ahmady-Asbchin et al., 2008; Dursun, 2006; Krim et al., 2006; Michalak et al., 2007; Chojnacka et al., 2005; Davis et al., 2003). Several researchers reported on biosorption uptake of phenols and dyes but very few reports found on removal of pesticides by biosorption (Allen et al., 2005; Bhattacharyya and Sharma, 2004; Calace et al., 2002; Juhasz et al., 2002; Tsezos and Bell, 1987; 1989).

The biosorbents used for accumulation/removal of organic or inorganic matter were derived form bacteria, fungi, algae, activated sludge, byproducts from fermentation industries or seaweeds (Hussain et al., 2009; Maurya et al., 2006). Microbial biomass, such as fungi, would be particularly cost effective as there are many food-processing plants in many countries that could provide wastewater as substrate at a very low cost for the cultivation of them. However, fungal biosorption has been studied more extensively because of the amenability of the microorganisms to genetic and morphological manipulation (Preetha and Viruthagiri, 2007). Most fungi are robust organisms and are generally more tolerant to high concentrations of polluting chemicals than bacteria. Important fungal biosorbents include Aspergillus (Fu and Viraraghavan,
2002; Benoit et al., 1998), Penicillium (Iscen et al., 2007) and Rhizopus (Tsezos et al., 1987; O'Mahony et al., 2002; Kumari and Abraham, 2007). Even if the mechanisms regulating biosorption have not yet been fully explained, it seems to take place essentially at the cell wall level. The cell wall of fungi consists of amino or nonamino-polysaccharides (Aksu, 2005). Use of dead cells for biosorption has greatly enhanced its applicability in the field of hazardous waste management since unlike live cells, dead cells do not require the maintenance of specific environment and supply of nutrients (Murleedharan, 1993).

In natural waters, various organic and inorganic substances are likely to be present along with endosulfan. Many researchers reported that the presence of certain inorganic and organic substances had influence on removal efficiency during a biosorption/adsorption process (Alam et al., 2002; Maurya et al., 2006). The presence of these elements may shows significant influence on the performance of biosorbent and it may be necessary to perform certain pretreatment to diminish their impacts. So, it becomes necessary to evaluate the interference caused in biosorption of endosulfan due to the presence of organic and inorganic substances in natural water in order to design integrated sorption treatment with impact of the substances of concern. In this study, biosorbent prepared from fungal culture Aspergillus Nidulans (ANS) exhibited the maximum sorption capacity of $43.55 \mathrm{mg} \mathrm{g}^{-1}$ for biosorption of endosulfan among all biosorbents, effectiveness was quantified in presence of different ionic strength and presence of organic substances such as surfactant, other pesticides, fertilizers and inorganic substances such as calcium ion, magnesium ions and chloride ions were examined.

\section{MATERIALS AND METHODS}

Microorganism and its growth conditions: Fungal culture, Aspergillus nidulans NCIM 1211 used in this study was procured from National Collection of Industrial Micro-organisms, National Chemical Laboratory, Pune, India. Aspergillus nidulans was grown in a fungal potato dextrose medium (NCIM 44). Fungal potato dextrose medium containing $\left(\mathrm{g} \mathrm{l}^{-1}\right)$ : Peeled potatoes, 200.00, Dextrose, 20.00, Yeast extract, 0.1 .The incubation was carried out at $37^{\circ} \mathrm{C}$ in orbital shaker incubator at $250 \mathrm{rpm}$ for 4 days.

Study of fungal growth: Growth studies were done to identify the active growth phase of fungal culture. Growth profile was analyzed over a time period of 120$132 \mathrm{~h}$ for Aspergillus nidulans during which the 
complete growth was expected. A set of flask, each containing $100 \mathrm{~mL}$ of growth medium, was inoculated with $1 \mathrm{~mL}$ fungal spores suspension and placed on a rotary platform incubator shaker maintained at $37^{\circ} \mathrm{C}$ to initiate growth of the fungus. One flask from the set was sacrificed every $6 \mathrm{hrs}$ to harvest the fungal biomass pellets of Aspergillus nidulans. The mycelia pellets were dried at $105^{\circ} \mathrm{C}$ to determine the dry weight of the biomass. Dry weight versus time graphs were plotted to identify the optimum time required for active growth phase of fungus. All experiments were performed in duplicates. Control experiments were also set-up in the absence of fungal inoculums to determine growth (if any) under biotic condition.

Preparation of biosorbent: Aspergillus Nidulans (ANS) was grown in an autoclaved NCIM 44 Potato dextrose medium with corresponding fungal spores (roughly $10 \%$ of the volume of medium). Test flasks were placed on rotary platform incubator shaker (Trishul equipments, Thane, Mumbai) maintained at $37^{\circ} \mathrm{C}-250 \mathrm{rpm}$ for 4 days. Spore inoculum was prepared under sterile conditions in $0.05 \%$ in Tween-80 using freshly grown and sporulating mat on potato dextrose agar plates. The mycelial pellets were harvested through filtering. The biomass was then washed repeatedly with distilled water to remove the growth medium adhering on its surface. The mycelial pallets used in this study were autoclaved at $121^{\circ} \mathrm{C}$ for 20 minutes. The biomass was then dried in an oven at $105^{\circ} \mathrm{C}$ for $12 \mathrm{hrs}$ and ground with a Remi Anupam Mixie laboratory grinder (Mumbai) and sieved to get particle size between 0.15-0.3 mm. The physicochemical properties of ANS biosorbent are shown in Table 1. Figure 1a shows the vegetative cells of Aspergillus nidulans and Fig. b shows the powdered form of ANS biosorbent.

Chemicals: All chemicals and reagents used were of analytical grade (AR). Technical grade endosulfan, atrazine and monocrotophos were provided by $\mathrm{M} / \mathrm{s}$ Vijiyalaxmi Insecticides and Pesticides Limited Andhra Pradesh. N-Hexane and Acetone were purchased from Merk India Ltd, Mumbai. All glassware used were of Borosil. Distilled water was used for making synthetic samples. Before every experiment, all glassware were cleaned with mixture of dilute chromic acid and soap solution followed by through washing with tap water and distilled water. Stock solution of endosulfan was prepared in acetone at a concentration of $100-1000 \mathrm{mg} \mathrm{mL}^{-1}$. All solutions were stored in the dark at $4^{\circ} \mathrm{C}$ prior to use.
Extraction of endosulfan from water: Extraction of endosulfan from water was done by liquid-liquid partition method. Representative sample of $2 \mathrm{~mL}$ of aqueous solution spiked with endosulfan was extracted in a $20 \mathrm{~mL}$ test tube. Extraction was done three times with 2, 2 and $2 \mathrm{~mL}$ of $\mathrm{n}$-Hexane, respectively. During the extraction process, the sample-hexane mixture was shaken for 60 seconds in multi tube vertex mixer (Trishul equipments, Thane, Mumbai). Then, allowed to settle for 1 minute. Hexane extract was collected in $20 \mathrm{~mL}$ test tube. Total $6 \mathrm{~mL}$-Hexane was collected as results of three times extraction. $1 \mathrm{~mL}$ from $6 \mathrm{~mL}$ extracted hexane was transferred to Teflon sealed septum bottles. $2 \mu \mathrm{L}$ of extracted sample was used for injecting into GC.

Table 1: Physical properties of the ANS biosorbent

\begin{tabular}{ll}
\hline Property & Value \\
\hline Specific gravity & 1.256 \\
Apparent density $\left(\mathrm{g} \mathrm{cm}^{3-1}\right)$ & 1.011 \\
Surface area $\left(\mathrm{m}^{2} \mathrm{gm}^{-1}\right)$ & $0.478^{\mathrm{a}}$ \\
Porosity $(\%)$ & 19.509 \\
Ash content (\%) & 0.95 \\
Hardness (as \% loss in attrition) & 1.00 \\
Other minerals & Silica, Phosphorous, \\
& Sulphur, Chloride, Potassium \\
\hline
\end{tabular}

As determined by ${ }^{\text {a}}$ : BET surface area method; ${ }^{b}$ : XRF (X-Ray Fluorescence Spectrometer) analysis

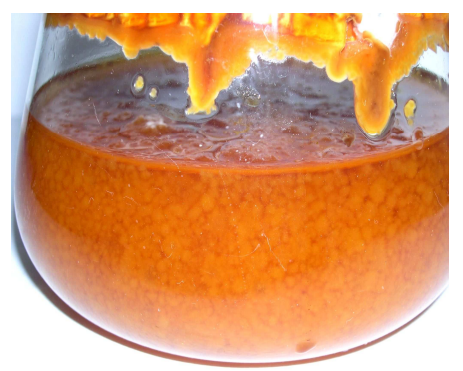

(a)

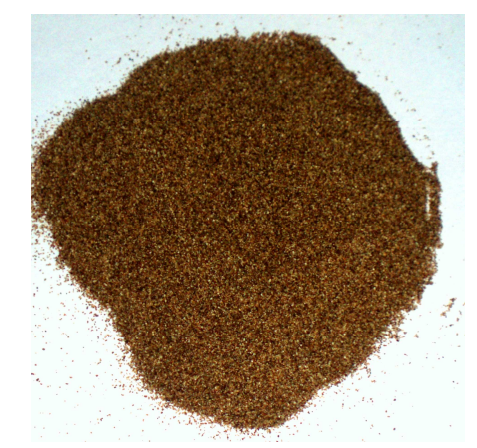

(b)

Fig. 1: (a) Vegetative cell of Aspergillus nidulans (b) Powdered ANS biosorbent 
Am. J. Environ. Sci., 7 (3): 224-236, 2011

Table 2: Experimental conditions investigated

\begin{tabular}{|c|c|}
\hline Parameters & Values investigated \\
\hline $\mathrm{PH}$ of the aqueous solution & $2.2,4,6.4,7.5,10$ and 11 \\
\hline Biosorbent size (mm) & $\begin{array}{l}0-0.075,0.15-0.30,0.425 \\
0.60 \text { and } 0.60-0.85\end{array}$ \\
\hline Ionic strength $(\mathrm{M})$ & $0.001,0.001,0.01,0.1$ \\
\hline Chloride concentration $\left(\mathrm{mg} \mathrm{L}^{-1}\right)$ & $25,50,100,150,200$ \\
\hline Calcium ion $\left(\mathrm{mg} \mathrm{L}^{-1}\right)$ & $10,30,50,90,110$ \\
\hline Magnesium ions $\left(\mathrm{mg} \mathrm{L}^{-1}\right)$ & $10,30,50,90,110,130$ \\
\hline $\begin{array}{l}\text { Fertilizers } \\
\text { (Urea,single super phosphate) }\left(\mathrm{mg} \mathrm{L}^{-1}\right)\end{array}$ & $10,20,50,80,100$ \\
\hline Surfactant $\left(\mathrm{mg} \mathrm{L}^{-1}\right)$ & $10,20,30,40,50$ \\
\hline Dissolved Organic matter $\left(\mathrm{mg} \mathrm{L}^{-1}\right)$ & $10,20,30,40$ \\
\hline Other pesticides & $0.1,0.2,0.4,0.6,0.8,1$, \\
\hline $\begin{array}{l}\text { (Atrazine and monocrotophos) } \\
\left(\mathrm{mg} \mathrm{L}^{-1}\right)\end{array}$ & 2,3 \\
\hline
\end{tabular}

Analytical procedures: Gas chromatograph (Agilent Technologies, model GC-6890N, USA) with electron capture detector and Agilent HP-5 column of $0.53 \mathrm{~mm}$ ID, $1.5 \mu \mathrm{m}$ film thickness and $30 \mathrm{~m}$ length was used for endosulfan n-Hexane extracts. Temperature of column, injector and detector was maintained at 280, 250 and $300^{\circ} \mathrm{C}$ respectively. Nitrogen $(99.9 \%$ purity) was used as carrier gas at a flow rate of $30 \mathrm{~mL} \mathrm{~min}^{-1}$.

Extraction of endosulfan from ANS biosorbent: The flasks containing endosulfan was separated from the fungal biosorbent by filtering through filter steady no. 201. Prior to filtration, the filters were washed with 300 $\mathrm{mL}$ of distilled water to remove any leachable materials. About $40-45 \mathrm{~mL}$ of extracted solution was filtered through the filter study to achieve biosorption equilibrium of filter study with the solution. This portion of filtrate was discarded. The subsequent filtrate was then extracted by n-Hexane as prescribed earlier and collected for GC analysis in teflon sealed septum bottles.

Kinetic studies in presence of different inorganic and organic substances: All batch sorption kinetic experiments were carried out using synthetic samples in distilled water at room temperature in mechanical shaker (Trishul Equipments, Mumbai, India). $50 \mathrm{~mL}$ of $1 \mathrm{mg} \mathrm{L}^{-1}$ endosulfan spiked distilled water samples containing $1 \mathrm{~g} \mathrm{~L}^{-1}$ of ANS biosorbent were taken in $100 \mathrm{~mL}$ screw-top flask and agitated at a constant speed of $250 \mathrm{rpm}$. After shaking for $12 \mathrm{~h}$, the samples were withdrawn for the analysis of endosulfan. In this study, effect of different $\mathrm{pH}$, biosorbent size, ionic strength, presence of inorganic substances such as calcium ion, magnesium ions, chloride ions, fertilizers and presence of organic substances such as Dissolved
Organic Matter (DOM), surfactant, other pesticides were examined.

In order to study the effect of $\mathrm{pH}$ on biosorption of endosulfan, experiments were conducted at different $\mathrm{pH}$ values ranging from 2.2-11, which were adjusted by adding either $0.1 \mathrm{~N} \mathrm{NaOH}$ or $0.1 \mathrm{~N} \mathrm{HCl}$. The initial and final $\mathrm{pH}$ values were analyzed using digital Scientific Sales Syndicate $\mathrm{pH}$ meter (India). The effect of biosorbent size was analyzed using four different size ranges $0-0.075,0.15-0.30,0.425-0.60$ and $0.60-0.85$ $\mathrm{mm}$. Using $\mathrm{NaNO}_{3}$, over the range of $10^{-3}-10^{-1} \mathrm{M}$, the effect of ionic strength on sorption of endosulfan was studied at room temperature. The effect of chloride concentration (as $\mathrm{Cl}^{-}$) was studied by adding different amounts of $\mathrm{NaCl}$ from $0-200 \mathrm{mg}^{-1} \mathrm{~L}$. The effect of $\mathrm{Ca}^{+2}$ and $\mathrm{Mg}^{+2}$ ions on the biosorption of endosulfan was studied, for a concentration range of $0-100 \mathrm{mg} \mathrm{L}^{-1}$. Effect of two fertilizers viz. Urea and Single Super Phosphate (SSP) on removal of endosulfan was conducted separately in the presence of $0-100 \mathrm{mg} \mathrm{L}^{-1}$ concentrations of both of them. The effect of the Dissolved Organic Matter (DOM) viz. humic acid and polyacrylic acid on the biosorption process was studied using different concentrations of DOM in a range of 0$40 \mathrm{mg} \mathrm{L}^{-1}$. The effect of sodium propionate surfactant on the sorption process of the endosulfan was quantified in concentration range of $0-50 \mathrm{mg} \mathrm{L}^{-1}$ of the surfactant. The effect of atrazine and monocrotophos were studied on removal of endosulfan at different concentration from $0.1-3 \mathrm{mg} \mathrm{L}^{-1}$ separately. The experimental conditions investigated are summarized in Table 2.

\section{RESULTS}

Effect of pH: The effect of $\mathrm{pH}$ on the equilibrium uptake capacity of endosulfan by ANS biosorbent at initial $\mathrm{pH} 2.2-11$ at initial concentration of $1 \mathrm{mg} \mathrm{L}^{-1}$ of endosulfan is shown in Fig. 2. The $\mathrm{pH}$ of the medium has minor effect on endosulfan biosorption. Endosulfan uptake was $0.89 \mathrm{mg} \mathrm{g}^{-1}, 0.9 \mathrm{mg} \mathrm{g}^{-1}$ and $0.82 \mathrm{mg} \mathrm{g}^{-1}$ at pH 2.2, 6.4-11, respectively.

Effect of biosorbent size: The variations in percent removal of endosulfan from the aqueous solution with biosorbent sizes of $0-0.075,0.15-0.30 \mathrm{~mm}, 0.425-0.60$ $\mathrm{mm}-0.60-0.85 \mathrm{~mm}$ is shown in Fig. 3. The percentage removal of endosulfan was increased from $78-90.4 \%$ as the biosorbent size decreases from 0.60-0.85-0.15-0.30 $\mathrm{mm}$. 
Am. J. Environ. Sci., 7 (3): 224-236, 2011

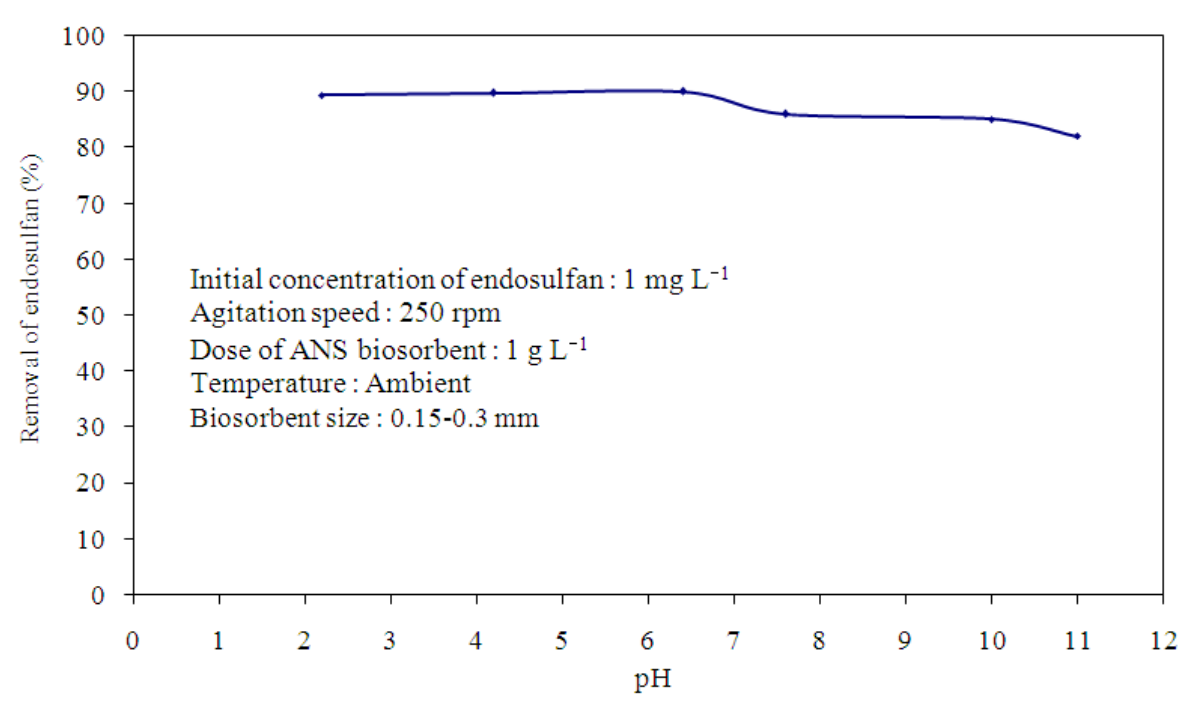

Fig. 2: Effect of $\mathrm{pH}$ on biosorption of endosulfan on to ANS biosorbent

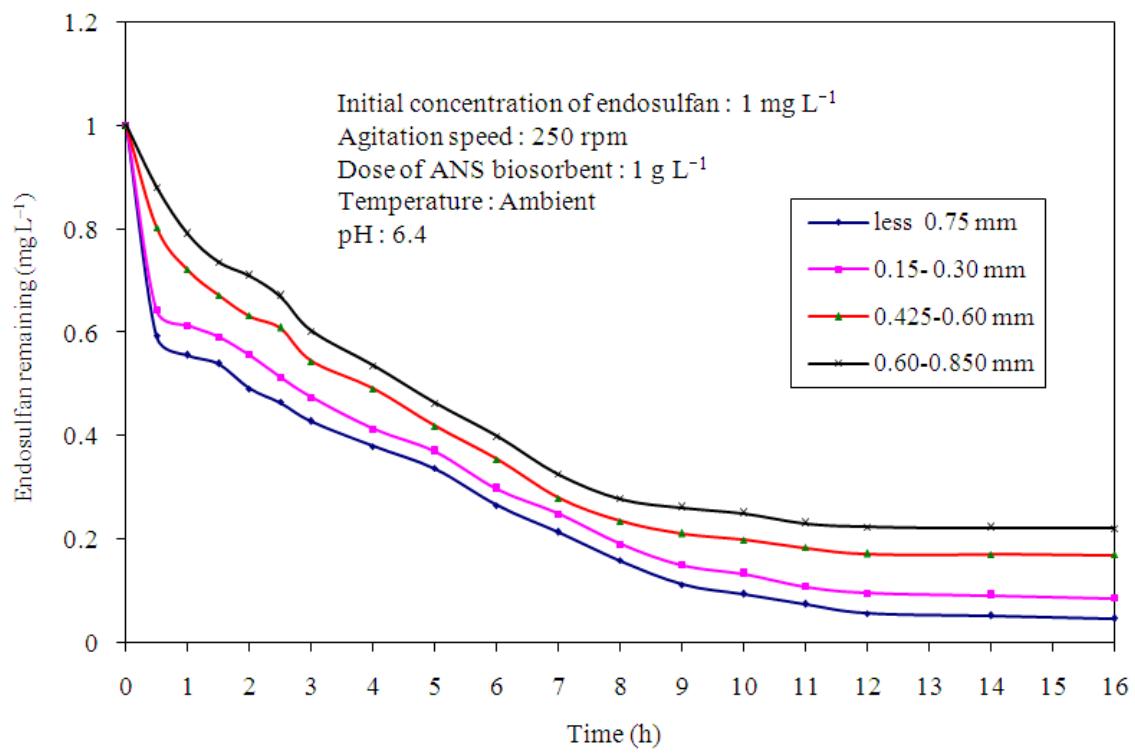

Fig. 3: Effect of biosorbent size on biosorption of endosulfan on to ANS biosorbent

Effect of ionic strength and inorganic ion concentration: Ionic strength of water is the capacity of water to ionize the sorbate. Generally the ionic strength of natural water is less than $10^{-3} \mathrm{M}$ (Briggs, 1981). Ionic strength influences biosorption by affecting the surface charge and the double-layer properties of the cells (Ju et al., 1997). In the present study effect of ionic strength on endosulfan sorption onto treated ANS biosorbent was studied in a range of 0 $10^{-4} \mathrm{M}$. The effect of ionic strength as equivalent of $\mathrm{NaNO}_{3}$ is shown in Fig. 4.
Very slight decrease of $1.9 \%$ was observed can not be considered as significant difference in removal of endosulfan because of change in ionic strength.

In the natural waters the limit of chloride concentration is $200 \mathrm{mg} \mathrm{L}^{-1}$. Effect of $\mathrm{Cl}^{-}$concentration on the sorption of endosulfan onto ANS biosorbent was tested in a range of $0-200 \mathrm{mg} \mathrm{L}^{-1} \mathrm{Cl}^{-}$. From Fig. 5, a slight reduction of $4.4 \%$ of biosorption of endosulfan was observed up to $200 \mathrm{mg} \mathrm{L}^{-1}$ of $\mathrm{Cl}^{-}$concentration. The effect of $\mathrm{Ca}^{+2}$ and $\mathrm{Mg}^{+2}$ on biosorption of endosulfan onto ANS biosorbent were found out in a wide range of concentrations. 
Am. J. Environ. Sci., 7 (3): 224-236, 2011

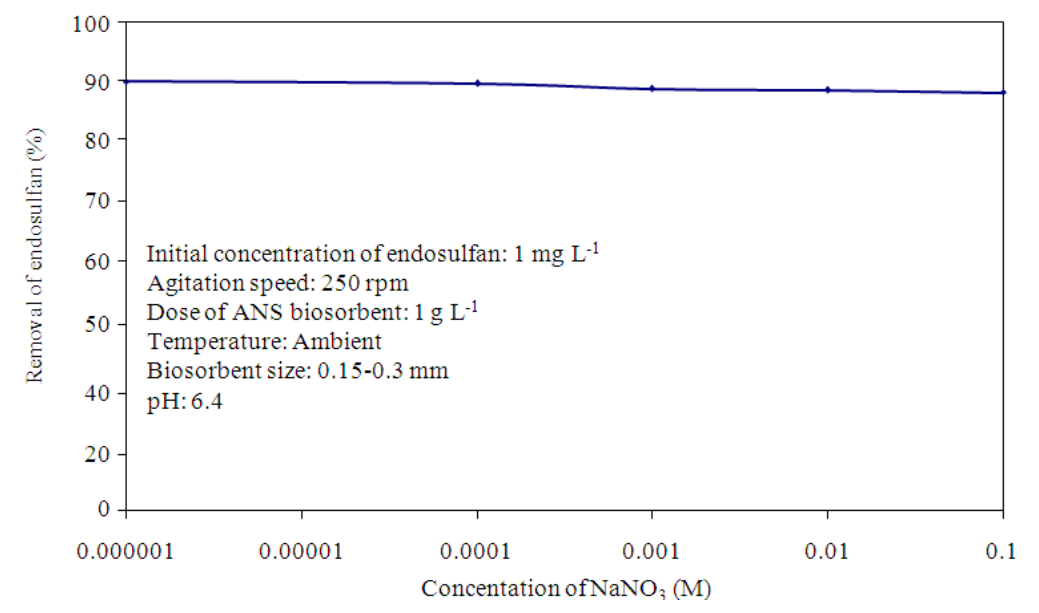

Fig. 4: Effect of ionic strength on biosorption of endosulfan on to ANS biosorbent

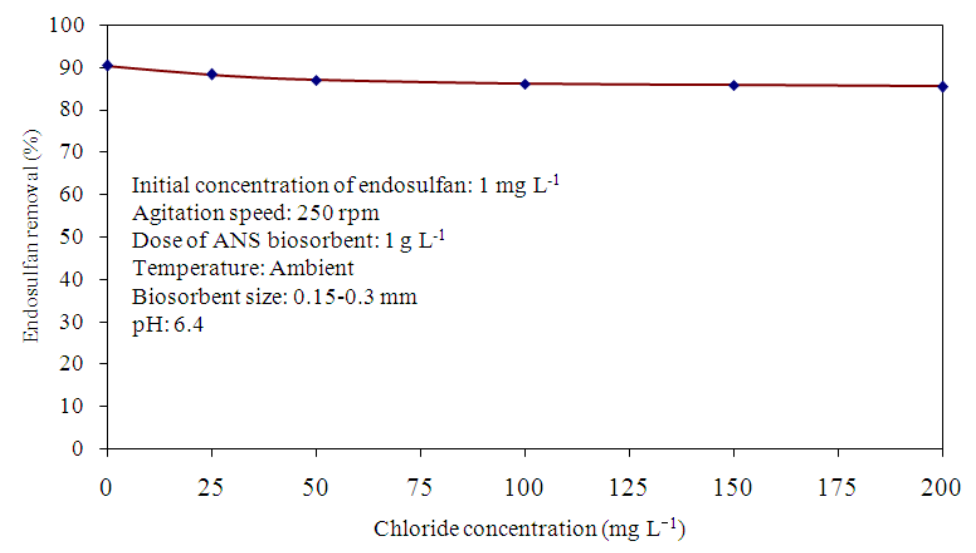

Fig. 5: Effect of chloride concentration on biosorption of endosulfan on to ANS biosorbent

Effect of $\mathrm{Ca}^{+2}$ was studied in a range of $0-110 \mathrm{mg} \mathrm{L}^{-1}$ concentrations whereas $\mathrm{Mg}^{+2}$ was studied for a range of $0-130 \mathrm{mg} \mathrm{L}^{-1}$. The effects of these two most common cations on endosulfan sorption are shown in Fig. 6. In a concentration range between $0-50 \mathrm{mg} \mathrm{L} \mathrm{L}^{-1}$, no significant effect of $\mathrm{Ca}^{+2}$ or $\mathrm{Mg}^{+2}$ have been observed on biosorption of endosulfan. But overall, the presence of $\mathrm{Ca}^{+2}$ and $\mathrm{Mg}^{+2}$ reduced the biosorption of the endosulfan on ANS biosorbent by 8 and $5.3 \%$ respectively.

Effect of fertilizers: Use of fertilizers along with pesticides is very common in agriculture field. Hence, it is important to find out the effect of fertilizers presence during the biosorption of endosulfan by ANS biosorbent. Here, the effects of generally used fertilizers namely, Urea (fertilizer grade, $45 \% \mathrm{~N}_{2}$ ) and Single Super Phosphate, SSP (fertilizer grade, $10 \% \mathrm{P}_{2} \mathrm{O}_{5}$ ), on biosorption of endosulfan were studied (Fig. 7). It was observed from the Fig. 7 that in case of Urea, the removal efficiency decreased about $4 \%$ in the concentration range of $80 \mathrm{mg} \mathrm{L}^{-1}$ urea. At a concentration of $100 \mathrm{mg} \mathrm{L}^{-1}$ the efficiency increased to $90 \%$. Whereas in the case of SSP, the reduction of biosorption of endosulfan was found $8.36 \%$.

Effect of surfactants: During the last decade considerable attention has been given to the presence of surfactants in the soil-water system. Land application of wastewater adds large amount of detergent products to the soil-water system and therefore, can result in an increase in dissolved organic content of the infiltrating water (Hutchins et al., 1985; Amiel et al., 1990). It is essential to consider the interaction of the hydrophobic pesticides with surfactants in removal process. Figure 8 shows the effect of surfactant (sodium propionate) on the biosorption of endosulfan at concentration range of $0-50 \mathrm{mg} \mathrm{L}^{-1}$. It can be seen from Fig. 8 that the presence of surfactant slightly reduced the removal efficiency of endosulfan by $5.36 \%$. 
Am. J. Environ. Sci., 7 (3): 224-236, 2011

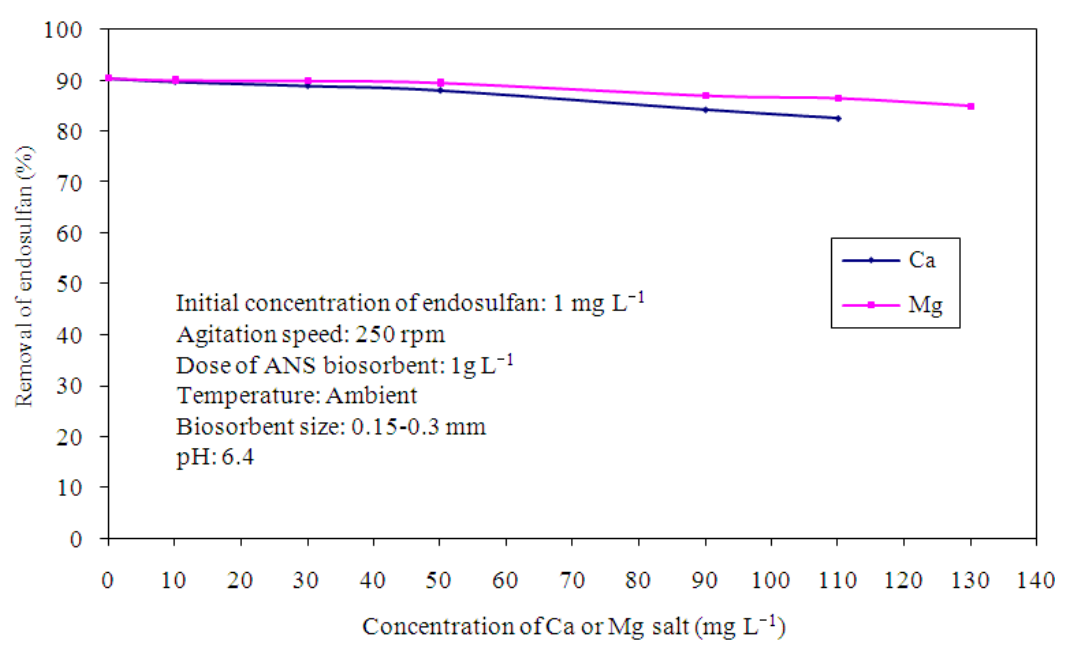

Fig. 6: Effect of $\mathrm{Ca}^{+2}$ and $\mathrm{Mg}^{+2}$ concentrations on biosorption of endosulfan on to ANS biosorbent

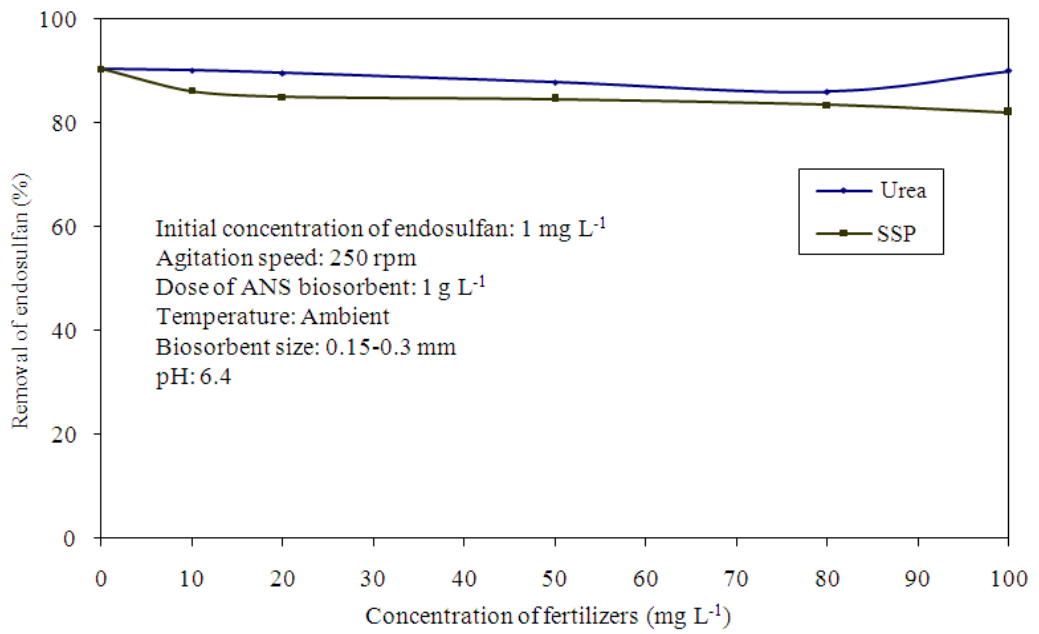

Fig. 7: Effect of Urea and SSP fertilizers on biosorption of endosulfan on to ANS biosorbent

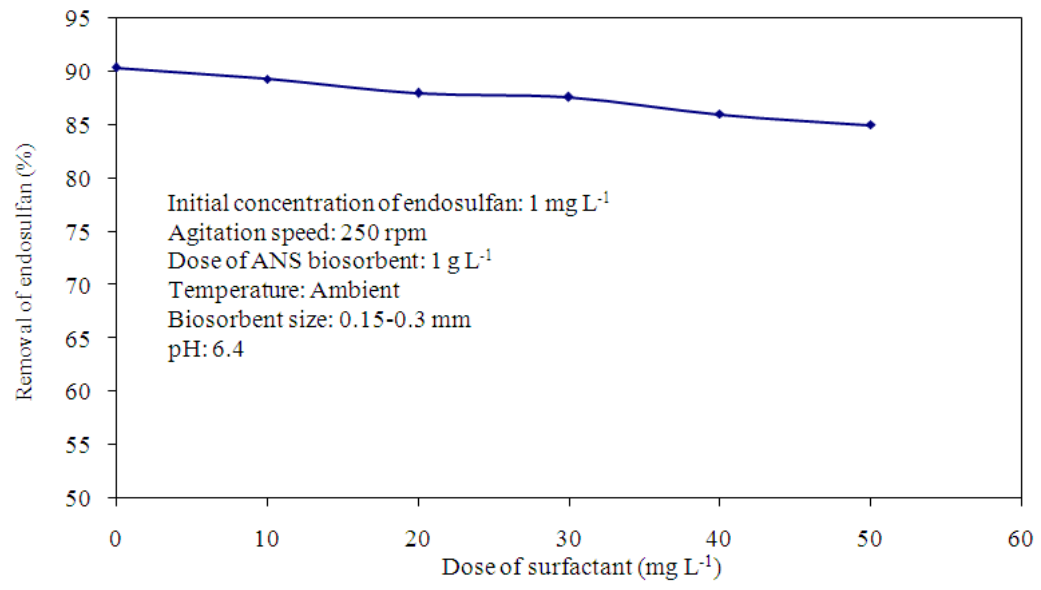

Fig. 8: Effect of surfactant on biosorption of endosulfan on to ANS biosorbent 
Am. J. Environ. Sci., 7 (3): 224-236, 2011

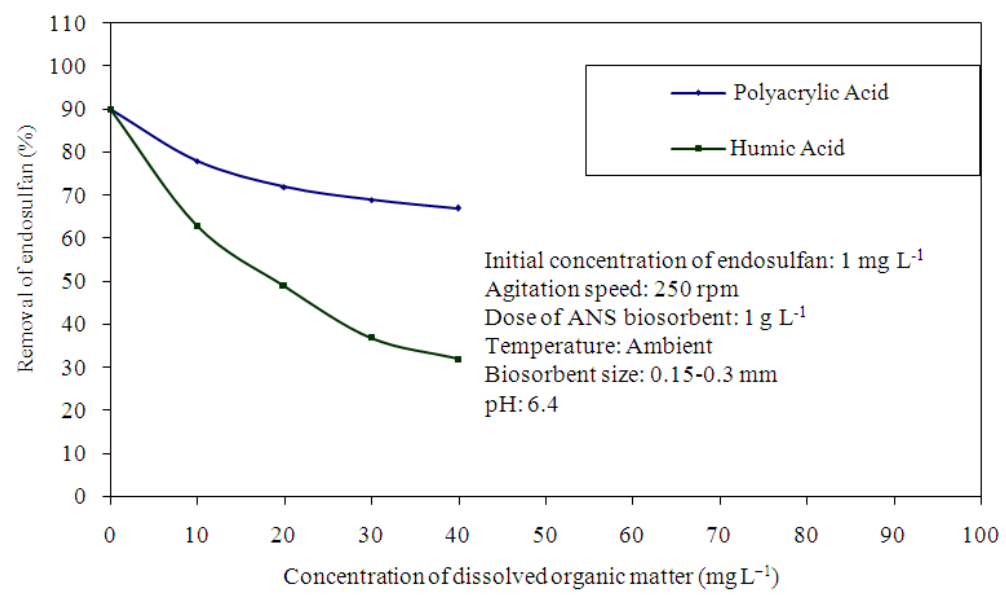

Fig. 9: Effect of dissolved organic matter on biosorption of endosulfan on to ANS biosorbent

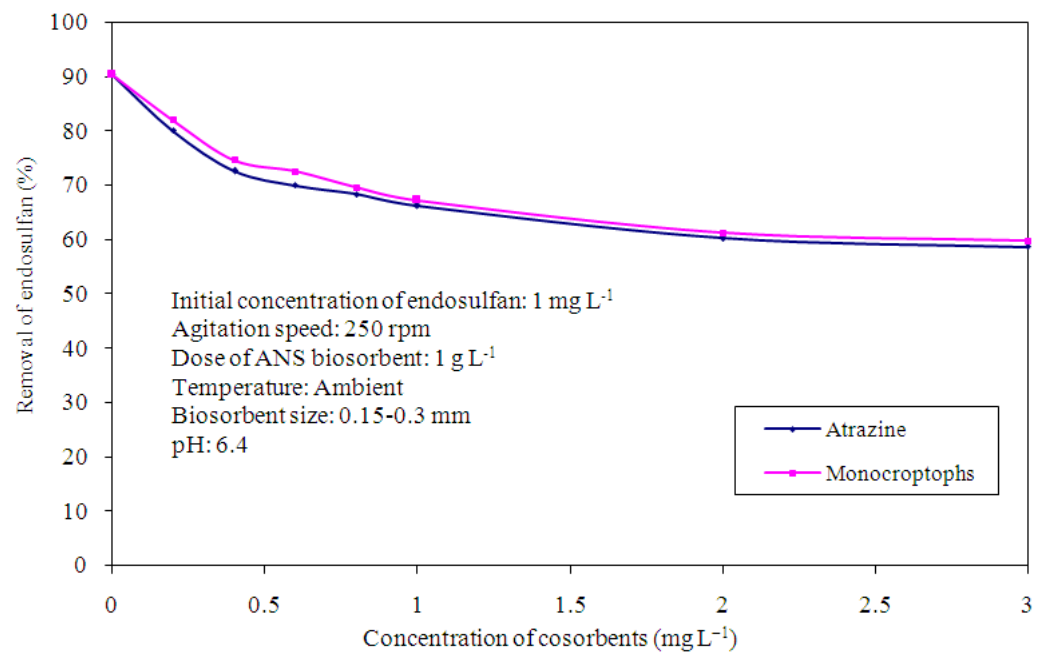

Fig 10: Effect of cosorbents on biosorption of endosulfan on to ANS biosorbent

Effect of dissolved organic matter: In natural and aquatic environments, large variety of natural and synthetic organic matters such as humic acid, fulvic acid, amino acids, polyacrylic acid and other chemicals from non-point sources are present (Takahashi et al., 1997). The interaction between the chlorinated herbicide viz. atrazine and insecticides viz. dieldrin and pentachloro-phenol with humic acid and fulvic acid was reported by Celis et al. (1998a) and Fabre et al. (1990). Some researchers reported that the presence of background organic substances such as humic acid had badly affected the adsorption efficiency of dieldrin, alachlor and heptachlor on activated carbon (Pirbazari and Weber, 1984; Pirbazari et al., 1991, Celis et al., 1998b). Therefore, the effect of humic acid and polyacrylic acid on biosorption of endosulfan at different concentrations was studied. Figure 9 shows that the removal efficiency of ANS biosorbent was hampered by 23 and $58 \%$ in presence of polyacrylic acid and humic acid, respectively in a concentration range of $0-40 \mathrm{mg} \mathrm{L}^{-1}$.

Effect of other pesticides: In agricultural fields, atrazine (herbicide) and monocrotophos (insecticide) are widely used in combination with endosulfan. So, there is a possibility of their presence in natural water environment along with endosulfan. Therefore, the effect of atrazine and monocrotophos on biosorption of endosulfan was studied.

Atrazine, an organochlorine herbicide and monocrotophos, an organophosphorous pesticide were tried with a concentration of $0-3 \mathrm{mg} \mathrm{L}^{-1}$ while keeping endosulfan concentration constant at $1 \mathrm{mg} \mathrm{L}^{-1}$ to examine the competitive effect of other co-sorbate. Figure 10 shows that biosorption of endosulfan was 
reduced by $24 \%$ with the increasing concentration of atrazine. Similarly, the presence of monocrotophos hampered the biosorption efficiency of endosulfan onto ANS biosorbent by $23 \%$.

\section{DISCUSSION}

Effect of pH: Extent of sorption influenced with change in $\mathrm{pH}$ of solution due to the change of surface properties of the biosorbent, the degree of ionization and the species of adsorbate. There was no significant effect found on endosulfan biosorption in acidic and basic range of $\mathrm{pH}$ compare to medium neutral $\mathrm{pH}$. Juhasz et al. (2002) reported similar finding for uptake of p-p'DDT by cladosporium strain $\mathrm{AJR}^{3} 18,501$. The uptake of p-p'DDT was minorly affected by change in $\mathrm{pH}$ value form 3-10. Young and Banks (1998) investigated the effect of different $\mathrm{pH}$ values (2.0 to 10.0 ) on the biosorption of lindane by heat treated $R$. oryzae and reported that biosorption was most effective at lower $\mathrm{pH}$. Extensive literature found on the effect of $\mathrm{pH}$ on the sorption of metals (Schiewer and Wong, 2000; Ramelow et al., 1992; Schiewer and Volesky, 1995). However, very scare information is available in case of pesticides.

Fungal culture Aspergillus nidulans consists of lipid, proteins and polysaccharides. Surface of ANS biosorbent is interwoven with different groups like carboxyl, hydroxyl, amines and amides etc. All groups are hydrolysed differently in aqueous phase. $\mathrm{pH}$ of the aqueous biosorbent suspension is the measure of the cumulative effect of the hydrolysis of different surface groups. The $\mathrm{pH}$ of the biosorbent suspension was 6.35 \pm 0.05 . It implies that in aqueous phase, biosorbent surface carries a net negative charge, which indicates the possibility of coulombic attraction between the biosorbent (negatively charged surface in the aqueous phase) and the endosulfan. In this study the natural state of $\mathrm{pH} 6.4$ without $\mathrm{pH}$ adjustment, the biosorption of endosulfan was of maximum level as shown in Fig. 2. Hence, the subsequent experiments were conducted in a natural medium without $\mathrm{pH}$ adjustment.

Effect of biosorbent size: Significant difference was found on sorption capacity of ANS biosorbent with decreasing size of biosorbent. Increase rate of biosorption with smaller size of biosorbent is due to the availability of number of active sites to the adsorbate. Many researchers reported the increased rate of sorption with decrease size of sorbent (Varma et al., 2010; Alam et al., 2002; Kim et al., 1997). Higher sorption capacities of smaller particles are due to the reduced diffusive path length into the interior of the sorbent particles and therefore energy requirement of adsorbate species can be reduced to move from one active site to another (Alam et al., 2002; Issam et al., 1990).

Effect of ionic strength and inorganic ion concentration: Minor reduction in sorption of endosulfan in presence of ionic strength is in agreement with the results reported by Alam et al. (2002). However, it contradictory to the results reported by Ju et al. (1997) who reported the increase in biosorption of lindane in presence of ionic strength on biosorbent prepared from Bacillus megaterium.

Endosulfan biosorption has been substantially affected in presence of $\mathrm{Ca}^{+2}$ compared to $\mathrm{Mg}^{+2}$. It has been observed that biosorption of $\mathrm{Ca}^{+2}$ and $\mathrm{Mg}^{+2}$ also take place along with endosulfan on the ANS biosorbent. Intra-particulate diffusion of $\mathrm{Ca}^{+2}$ and $\mathrm{Mg}^{+2}$ on the surface of ANS biosorbent might be responsible for the same. Rubin (1974) reported that the sorption potential of cations increases with decreasing electronegativity value. The lower electronegativity value of $\mathrm{Ca}^{+2}$ (i.e., 1 for $\mathrm{Ca}^{+2}$ and 1.5 for $\mathrm{Mg}^{+2}$ ) than $\mathrm{Mg}^{+2}$ could be the responsible for the more biosorption of $\mathrm{Ca}^{+2}$ as compared to $\mathrm{Mg}^{+2}$ on ANS biosorbent as observed in this study (Alam et al., 2002).

Effect of fertilizers: It was found that solubility of organic matter is increased in presence of Urea (Greece and Garner, 1983). As the ANS biosorbent constitutes major fraction of chitinous material which provides biosorption sites for endosulfan molecules. The presence of Urea might have altered the chitin-binding domain (Fan et al., 2007) and thus, there might be fall in removal efficiency in the range of concentrations up to of $80 \mathrm{mg} \mathrm{L}^{-1}$. At concentration of $100 \mathrm{mg} \mathrm{L}^{-1}$, there may be considerable hydrolysis of endosulfan to endosulfan sulphate $\left(\mathrm{C}_{9} \mathrm{H}_{6} \mathrm{Cl}_{6} \mathrm{O}_{4} \mathrm{~S}\right)$, resulting in improvement of sorption efficiency.

SSP consists of two parts of mono calcium phosphate and three parts of gypsum by weight. The presence of $\mathrm{Ca}^{+2}$ ions in SSP fertilizer can be the reason for reduction in biosorption of endosulfan as it was found already that the removal of endosulfan was hampered due to the competitive sorption of $\mathrm{Ca}^{+2}$ ions onto ANS biosorbent. However, change of 4 and $8.36 \%$ due to Urea and SSP should be considered as insignificant.

Effect of surfactants: Surfactant has the ability to enhance the apparent solubility of soluble organic compounds. Micelle forming characteristics of 
surfactants might also enhance the solubilization of organic contaminants by surfactants (Seo et al., 2000). The apparent solubility enhancement of endosulfan by the surface molecules may be the reason for the slight reduction of $5.36 \%$ in biosorption of endosulfan. Same result has been observed by study conducted by Beigel et al. (1998). They reported that the nonionic and anionic surfactants had very insignificant effect on triticonazole adsorption. Since $5.36 \%$ reduction is insignificant, the presence of surfactant is not an apprehension problem in case of endosulfan biosorption.

Effect of dissolved organic matter: Endosulfan removal efficiency was significantly hampered by $23 \%$ and $58 \%$ in presence of polyacrylic acid and humic acid, respectively. According to Chiou et al. (1986) that the solubility enhancement of solute could be due to interaction of the solute with the "microscopic organic environment". The apparent solubility enhancement of endosulfan by humic acid and polyacrylic acid molecules could be the reason for reduction in biosorption of endosulfan on ANS biosorbent. The presence of polyacrylic acid in endosulfan biosorption process played less significant effect than the presence of humic acid. The reason could be the less ability of polyacrylic acid to enhance endosulfan solubility. The presence of DOM causes significant effect on efficiency of biosorbent and hence, their removal may be desirable.

Effect of other pesticides: It is expected that competitive adsorption will play major role in the adsorption process from a multi-solute solution (David et al., 2007; El-Naas et al., 2007; Wang and Ariyanto, 2007). The decrease of endosulfan biosorption in the presence of atrazine could be attributed to the site competition between atrazine and endosulfan molecules. Usually the nonpolar adsorbents have more affinity towards the more hydrophobic molecules (Weber, 1972). Atrazine is more hydrophobic than endosulfan, which might be the reason for its preferential biosorption on to ANS biosorbent. Similarly, more hydrophilic nature of monocrotophos may be responsible for the hindering effect. Competitive biosorption and complexation may also contribute further.

\section{CONCLUSION}

It is evident from above discussion that the exogenous parameters played important role in the biosorption of endosulfan by ANS biosorbent. Effect of ionic strength was studied in the range of $0-10^{-4} \mathrm{M}$ and there was no significant effect on endosulfan removal. Effect of chlorides was insignificant except at a concentration of $200 \mathrm{mg} \mathrm{L}{ }^{-1}$. $\mathrm{Ca}^{+2}$ and $\mathrm{Mg}^{+2}$ at a concentration range of $0-110 \mathrm{mg} \mathrm{L}^{-1}$ and $0-130 \mathrm{mg} \mathrm{L}^{-1}$, respectively, did not show much effect except for small variations at a short range of concentrations. As fertilizers are likely to be present along with endosulfan in natural waters, the effect of Urea (fertilizer grade, $45 \% \mathrm{~N}_{2}$ ) and Single Super Phosphate, SSP (fertilizer grade, $10 \% \quad \mathrm{P}_{2} \mathrm{O}_{5}$ ) was determined separately at a concentration range of $0-100 \mathrm{mg} \mathrm{L}^{-1}$. Urea had inhibited the efficiency at a concentration range of 50$80 \mathrm{mg} \mathrm{L}^{-1}$ (about $4 \%$ ). In case of SSP, the effect was more or less in significant. Surfactant inhibited the efficiency at the higher concentration $20-50 \mathrm{mg} \mathrm{L}^{-1}$. The removal efficiency of endosulfan ANS biosorbent was affected considerably by humic acid and polyacrylic acid accounting for about 58\% and 23\% reduction respectively. Atrazine and monocrotophos the common coexisting pesticide, showed increasing trend of inhibition with concentration. It can be conclude from that there is a need for pretreatment in order to design integrated endosulfan biosorption treatment with concern of the substances present along with endosulfan in water environment.

\section{ACKNOWLEDGEMENT}

The researchers would like to thank $\mathrm{M} / \mathrm{s}$ Vijayalakshmi Insecticides, India, for providing technical grades of endosulfan, atrazine and monocrotophos respectively for carrying out research outlined in the present research study.

\section{REFERENCES}

Ahluwalia, S.S. and D. Goyal, 2007. Microbial and plant derived biomass for removal of heavy metals from wastewater. Bioresour. Technol., 98: 22432257. DOI: $10.1016 /$ j.biortech.2005.12.006

Ahmady-Asbchin, S., Y. Andres, C. Gerente and P.L. Cloirec, 2008. biosorption of cu (ii) from aqueous solution by Fucus serratus: surface characterization and sorption mechanisms. Bior. Tech., 99: 6150-6155. DOI: 10.1016/j.biortech.2007. 12.040

Aksu, Z., 2005. Application of biosorption for the removal of organic pollutants. Rev. Proc. Bioch., 40: 997-1026. DOI: 10.1016/j.procbio.2004.04.008

Alam, J.B., A.K. Dikshit and M. Bandyophadyay, 2002. Effect of different inorganic and organic compounds on sorption of 2,4-D and atrazine. J. Environ. Sci. Health Part B-Pesticides, Food Contam. Agric. Wast., 37: 541-560. DOI: 10.1081/PFC-120015438 
Allen, S.J., Q. Gan., R. Matthews and P.A. Johnson, 2005. Kinetic modeling of the adsorption of basic dyes by kudzu. J. Collo. Int. Sci., 286: 101-109. DOI: $10.1016 /$ j.jcis.2004.12.043

Amiel, A.J., M. Magartiz, D. Ronen and O. Lindstrand, 1990. Dissolved organic carbon in the unsaturated zone under land irrigation by wastewater effluent. J. Water Poll. Con. Fed., 62: 861-866. http://www.jstor.org/stable/25043928

Beigel, C., E. Barriuso and R. Calvet, 1998. Sorption of low levels of nonionic and anionic surfactants on soil: effects on sorption of triticonazole fungicide. Pestic. Sci., 54: 52-60. DOI: 10.1002/(SICI)10969063(199809)

Benoit, P., E. Barriuso and R. Calvet, 1998. Biosorption characterization of herbicides, 2, 4-D and atrazine and 2 chlorophenols on fungal mycelium. Chemosphere, 37: 1271-1282. DOI: 10.1016/S0045-6535(98)00125-8

Bhattacharyya, K.G. and A. Sharma, 2004. Azadirachta indica leaf powder as an effective biosorbent for dyes: a case study with aqueous Congo red solutions. J. Environ. Manage., 71: 217-229. DOI: 10.1016/j.jenvman.2004.03.002

Briggs, G.G., 1981. Theoretical and experimental relationships between soil adsorption, octanolwater partition coefficients, water solubilities, bioconcentration factors and the parachor. J. Agric. Food Chem., 29: 1050-1059. DOI: 10.1021/jf00107a040

Calace, N., E. Nardi, B.M. Petronio and M. Pietroletti, 2002. Adsorption of phenols by study mill sludges. Environ. Pollut., 118: 315-319. DOI: 10.1016/S0269-7491(01)00303-7

Celis, R., E. Barriuso and S. Houot, 1998b. Sorption and desorption of atrazine by sludge-amended soil: dissolved organic matter effects. J. Environ. Q., 27: 1348-1356. ISSN: 0047-2425

Celis, R., E. Barriuso and S.S. Houot, 1998a. Effect of liquid sewage sludge addition on atrazine sorption and desorption by soil, Chemosphere. 37: 10911107. DOI: $10.1016 / \mathrm{S} 0045-6535(98) 00108-8$

Chiou, C.T., R.L. Malcolm, T.I. Brinton and D.E. Kile, 1986. Water solubility enhancement of some organic pollutants and pesticides by dissolved humic and fluvic acids. Environ. Sci. Tech., 9: 5258. DOI: 10.1021/es00147a010

Chojnacka, K., A. Chojnackis and H. Gorecka, 2005. Biosorption of $\mathrm{Cr}^{3+}, \mathrm{Cd}^{2+}$ and $\mathrm{Cu}^{2+}$ ions by bluegreen algae Spirulina spp.: Kinetics, equilibrium and the mechanism of the process. Chemosphere, 59: 75-84. DOI: 10.1016/j.chemosphere.2004.10.005
David, K., N. Dan and R. Tannenbaum, 2007. Competitive adsorption of polymers on metal nano particles. Surf. Sci., 601: 1781-1788. DOI: 10.1016/j.susc.2007.01.054

Davis, T.A., B. Volesky and A. Mucci, 2003. A review of the biochemistry of heavy metal biosorption by brown algae. Water Res., 37: 4311-4330. DOI: 10.1016/S0043-1354(03)00293-8

Dursun, A.Y., 2006. A comparative study on determination of the equilibrium, kinetic and thermodynamic parameters of biosorption of copper (II) and lead (II) ions onto pretreated Aspergillus niger. Biochem. Eng. J., 28: 187-195. DOI: $10.1016 /$ j.bej.2005.11.003

El-Naas, M.H., F. Abu Al-Rub, I. Ashour and M. Al Marzouqi, 2007. Effect of competitive interference on the biosorption of lead (II) by Chlorella vulgaris, Chem. Engg. Proc., 46: 1391-1399. DOI: 10.1016/j.cep.2006.11.003

Fabre, B., J. Ayele, M. Mazet and P. Lafrance, 1990. Removal of penatchlorophenol by adsorption on to various material: The effect of organic coadsorbates. Rev. Sci. Educ., 3: 277-292. ISSN: 0992-7158

Fan, Y., W. Fang, S. Guo, X. Pe and Y. Zhang et al., 2007. Increased insect virulence in Beauveria bassiana strains over expressing an engineered chitinase. Applied Environ. Micro., 73: 295-302. DOI: 10.1128/AEM.01974-06

Farre, M.J., X. Xavier and J. Peral, 2006. Assessment of photo-fenton and biological treatment coupling for Diuron and Linuron removal from water. Water Res., $\quad 40$ : 2533-2540. DOI: 10.1016/j.watres.2006.04.034

Francis, B.R. and G.F. Lee, 1972. Adsorption of lindane and dieldrin pesticides on unconsolidated aquifer sands. Environ. Sci. Technol., 6: 538-543. DOI: 10.1021/es60065a009

$\mathrm{Fu}, \mathrm{Y}$. and T. Viraraghavan, 2002. Dye biosorption sites in Aspergillus niger. Bioresour Technol., 82: 139-145. DOI: 10.1016/S0960-8524(01)00172-9

Gonzalez-Pradas, E., M. Villafranca-Sanchez, A. Gallege-Campo, D. Urena-Amate and $M$. Fernandez-Perez. 1997. Removal of atrazine from aqueous solution by natural and activated bentonite. J. Environ. Qual., 26: 1288-1291. ISSN: 0047-2425

Gora, A., B. Toepfer, V. Puddu and G. Puma. 2006. Photocatalytic oxidation of herbicides in singlecomponent and multicomponent systems: Reaction kinetics analysis. Applied Catalysis B: Environ., 65: 1-10. DOI: 10.1016/j.apcatb.2005.12.009 
Goswami, S., K. Vig and D.K. Singh, 2009. Biodegradation of alpha and beta endosulfan by Aspergillus sydoni. Chemosphere, 75: 883-888. PMID: 17252313

Greece, P.A.P. and Z.M. Garner. 1983. Micelle catalysis in the aqueous inter molecular dials-adder reaction: Rate acceleration and enhanced selectivity. Tetrahedron Lett., 24: 1897-1983. DOI: 10.1016/S0040-4039(00)81800-6

Gupta, V.K., C.K. Jainb, I. Alib, S. Chandra and S. Agarwal, 2002. Removal of lindane and malathion from wastewater using bagasse flyash from sugar industry. Waste. Water Res., 36: 2483-2490. DOI: 10.1016/S0043-1354(01)00474-2

Hussain, M.A., A. Salleh and P. Milow, 2009. Characterization of the adsorption of the lead (II) by the nonliving biomass spirogyra neglecta (Hasall) Kützing. Am. J. Biochem. Biotechnol., 5: 75-83. DOI: 10.3844/ajbbsp.2009.75.83

Hutchins, S.R., M.B. Tomson, P.B. Bedient and C.H. Ward, 1985. Fate of trace organics during land application of municipal wastewater. Critical Rev. Environ. Cont., 15: 355-416. DOI: 10.1080/10643388509381737

Iscen, C.F., I. Kiran and S. Ilhan, 2007. Biosorption of reactive black 5 dye by Penicillium restrictum. J. Haz. Mat., 143: 335-340. PMID: 17034944

Issam, N.N., V.L. Snoeyink, M.T. Suidan, C.H. Lee and Y. Richard, 1990. Effect of particle size and background natural organic on the sorption efficiency of powdered activated carbon. J. Am. Water Works Assoc. 82: 65-72. http://apps.awwa.org/waterlibrary/scholarabstract.a spx?an=0026622.

Ju, Y.H., T.C. Chen and J.C. Liu, 1997. A study on the biosorption of lindane, Collo. Surface B, 9: 187196. DOI: 10.1016/S0927-7765(97)00019-2

Juhasz, A.L., E. Smith, J. Smith and R. Naidu, 2002. Biosorption of organochlorine pesticides using fungal biomass. J. Indus. Micro. Biotech. 29: 163169. DOI: $10.1038 /$ sj.jim.7000280

Jury, W.A., W.F. Spencer and W.J. Farmer, 1984. Behavior assessment model for trace organics in soil: III application of screening model. J. Environ. Qual., 13: 573-579. ISSN: 0047-2425

Katsoyiannis, A. and C.C. Samara, 2005. Persistent organic pollutants (Pops) in the conventional activated sludge treatment process: Fate and mass balance. Environ. Res., 97: 245-257. DOI: 10.1016/j.envres.2004.09.001

Kim, J.Y., J.K. Park and T.B. Edil, 1997. Sorption of organic compounds in the aqueous phase onto tire rubber. J. Environ. Eng. Div. (Am. Soc. Civ. Eng.), 123: 827-834. DOI: 10.1061/(ASCE)07339372(1997)123:9(827)

Kiso, Y., Y. Sugiura, T. Kitao and K. Nishimura, 2001. Effects of hydrophobicity and molecular size on rejection of aromatic pesticides with nanofiltration membranes. J. Mem. Sci., 92: 1-10. DOI: 10.1016/S0376-7388(01)00411-2

Kouras A., A. Zouboulis, C. Samara and T. Kouimtzis, 1998. Removal of pesticides from aqueous solutions by combined physicochemical processesthe behavior of lindane. Environ. Poll., 103: 193202. DOI: 10.1016/S0269-7491(98)00124-9

Krim, L., S. Nacer and G. Bilango, 2006. Kinetics of chromium sorption on biomass fungi from aqueous solution. Am. J. Environ. Sci., 2: 27-32.DOI: 10.3844/ajessp.2006.27.32 URL: http://www.thescipub.com/abstract/10.3844/ajessp. 2006.27.32

Kumari, K. and T.E. Abraham, 2007. Biosorption of anionic textile dyes by nonviable biomass of fungi and yeast. Bioreso. Tech., 98: 1704-1710. DOI: 10.1016/j.biortech.2006.07.030

Maldonado, M.I., S. Malato, L.A. Perez-Estrada, W. Gernjak and I. Oller et al., 2006. Partial degradation of five pesticides and an industrial pollutant by ozonation in a pilot-plant scale reactor. J. Hazard. Mat., 138: 363-369. DOI: 10.1016/j.jhazmat.2006.05.058

Maurya, N., A. Mittal, P. Cornel and E. Rother, 2006. Biosorption of dyes using dead macro fungi: Effect of dye structure, ionic strength and $\mathrm{pH}$. Bio. Tech., 97: 512-521. DOI: 10.1016/j.biortech.2005.02.045

Michalak, I., A. Zielińska, K. Chojnacka and J. Matuła, 2007. Biosorption of $\mathrm{Cr}$ (III) by microalgae and macroalgae: Equilibrium of the process. Am. J. Agric. Biol. Sci., 2: 284-290. DOI: 10.3844/ajabssp.2007.284.290

Murleedharan, T.R., 1993. Studies on the Metal Uptake Potential, Mechanism and of Biosorbent Ganoderma Lucidum. ph.D. Thesis, IIT Kanpur, India.

O’Mahony, T., E. Guibal and J.M. Tobin, 2002. Reactive dye biosorption by Rhizopus arrhizus biomass. Enzyme Micro. Tech., 31: 456-463. DOI: 10.1016/S0141-0229(02)00110-2.

Oller, I., W. Gernjak, M.I. Maldonado, L.A. PerezEstrada and J.A. Sanchez-Perez etal., 2006. Solar photocatalytic degradation of some hazardous water-soluble pesticides at pilot-plant scale. J. Hazar. Mat., 138: 507-517. DOI: 10.1016/j.jhazmat.2006.05.075 
Pirbazari, M. and W.J. Weber, 1984. Removal of dieldrin from water by activated carbon, J. Environ. Eng. Div., ASCE, 110: 656-669. DOI: 10.1061/(ASCE)0733-9372(1984)110:3(656)

Pirbazari, M.B., B.N. Badris and R.J. Miltener, 1991. GAC adsorber design for removal of chlorinated pesticides, J. Environ. Eng. Div., ASCE, 117: 8099. DOI: 10.1061/(ASCE)07339372(1991)117:1(80)

Preetha, B. and T. Viruthagiri, 2007. Batch and continuous biosorption of chromium (VI) by Rhizopus arrhizus. Sepa. Pur. Tech., 57: 126-133. DOI: 10.1016/j.seppur.2007.03.015

Ramelow, G.J, D. Fralick and Y. Zhao, 1992. Factors affecting the uptake of aqueous metal ions by dried sea weed biomass. Microbios, 72: 81-93. ISSN: 0026-2633

Rana, M.S., M.A. Halim, S. Safiullah, M. MamunMollah and M.S. Azam et al., 2009. Removal of heavy metal from contaminated water by biopolymer crab shell chitosan. J. Applied Sci., 9: 2762-2769.

http://www.doaj.org/doaj?func=abstract\&id=60490 9

Rubin, A.J., 1974. Aqueous-Environmental Chemistry of Metals, Ann Arbor Science publishers Inc., Michigan, USA. ISBN-10: 025040060X

Schiewer, S. and B. Volesky, 1995. Modeling of proton-metal ion exchange in biosorption. Environ. Sci. Tech., 29: 3049-3058. DOI: 10.1021/es00012a024

Schiewer, S. and M.H. Wong, 2000. Ionic strength effects in biosorption of metals by marine algae. Chemosphere, 41: 271-282. DOI: 10.1016/S00456535(99)00421-X

Seo, Y., R.D. Paode and T.M. Holsen, 2000. Partitioning of SSOCs into straight chained surfactants. J. Environ. Eng. Div., 126: 467-470. DOI: $\quad$ 10.1061/(ASCE)0733-9372(2000)126: 5(467)

Shaalan, H.F., M.Y. Ghaly and J.Y. Farah, 2007. Techno economic evaluation for the treatment of pesticide industry effluents using membrane schemes. Desalination, 204: 265-276. DOI: 10.1016/j.desal.2006.04.032

Sudhakar, Y. and A.K. Dikshit, 1999. Adsorbent selection for endosulfan removal from water environment. J. Environ. Sci. Health-Part B., 34: 97-118. PMID: 10048207
Sudhakar, Y. and A.K. Dikshit, 2001. Removal of endosulfan using aerobic mixed bacterial culture. I. J. Environ. Pollut. 15: 543-552. DOI: 10.1504/IJEP.2001.004922

Takahashi, Y., Y. Minai, S. Ambe, Y. Makide and F. Ambe et al., 1997. Simultaneous determination of stability constants of humate complexes with various metal ions using multi tracer technique. Sci. Total Environ., 198: 61-71. DOI: 10.1016/S0048-9697(97)05442-9

Thacker, N.P., M.V. Vaidya, M. Sipani and A. Kalra, 1997. A removal technology for pesticide contaminants in potable water. J Environ. Sci. Heal., B: 32: 483-96. ISSN: 0360-1234

Tsezos, M. and J.P. Bell, 1987. Removal of hazardous organic pollutants by adsorption on microbial biomass. Water Res. Technol., 19: 409-416. http://www.iwaponline.com/wst/01903/wst019030 409.htm

Tsezos, M. and J.P. Bell, 1989. Comparison of the biosorption and desorption of hazardous organic pollutants by live and dead biomass. Water Res., 23: 561-568. DOI: 10.1016/0043-1354(89)90022-5

Varma, D.S.N.R., Ch. Srinivas, Ch. Nagamani, T. PremSagar and M. Rajsekhar, 2010. Studies on biosorption of Cadmium on Psidium guajava leaves powder using statistical experimental design. J. Chem. Pharm. Res., 2: 29-44. ISSN: 0975-7384

Wang, S. and E. Ariyanto, 2007. Competitive adsorption of malachite green and $\mathrm{Pb}$ ions on natural zeolite. J. Coll. Inte. Sci., 314: 25-31. DOI: 10.1016/j.jcis.2007.05.032

Weber, W.J., 1972. Physicochemical Process for Water Quality Control. 1st Edn., John Wiley, New York, ISBN-10: 0471924350, pp: 672.

Young, E. and C.J. Banks, 1998. The removal of lindane from aqueous solution using a fungal biosorbent: The influence of $\mathrm{pH}$, temperature, biomass concentration and culture age. Environ Technol., 19: 619-625. DOI: $10.1080 / 09593331908616718$ 